\title{
Fermentative Production of Mannosylerythritol Lipids using Sweetwater as Waste Substrate by Pseudozyma antarctica (MTCC 2706)
}

\begin{abstract}
Mannosylerythritol lipids are glycolipid biosurfactants with promising industrial applications. However, their commercial production is hindered due to its high production cost. The current study investigates the use of sweetwater, a by-product of the fatsplitting industry in combination with soybean oil for the production of mannosylerythritol lipids using Pseudozyma antarctica (MTCC 2706). The optimum sweetwater and soybean oil concentration of $22 \%$ and $7 \%(\mathrm{w} / \mathrm{v})$ yielded $7.52 \mathrm{~g} \mathrm{~L}^{-1}$ and $21.5 \mathrm{~g} \mathrm{~L}^{-1}$ mannosylerythritol lipids at shake flask and fermenter level respectively. The structure and functional groups of mannosylerythritol lipids were confirmed by fourier transform infrared (FTIR) spectroscopy, liquid chromatography-mass spectrometry (LC/MS) and ${ }^{1} \mathrm{H}$ - and ${ }^{13} \mathrm{C}$-nuclear magnetic resonance (NMR) analysis. Surfactant properties, such as surface tension, critical micelle concentration, foaming and emulsification of mannosylerythritol lipids were also explored.
\end{abstract}

Keywords: biosurfactant, fermentation, mannosylerythritol lipids (MEL), Pseudozyma antarctica, sweetwater

\section{Fermentative Herstellung von Mannosylerythritollipiden aus Pseudozyma antarctica (MTCC 2706) unter Verwen- dung von Süßwasser als Abfallsubstrat.}

Zusammenfassung: Mannosylerythritollipide sind Glykolipid-Biotenside mit vielversprechenden industriellen Anwendungen. Ihre kommerzielle Produktion wird jedoch aufgrund ihrer hohen Produktionskosten behindert. In dieser Studie wurde die Verwendung von Süßwasser, das als Nebenprodukt bei der industriellen Fettspaltung anfällt, in Kombination mit Sojaöl bei der Herstellung von Mannosylerythritollipiden aus Pseudozyma antarctica (MTCC 2706) untersucht. Die optimale Süßwasser- und Sojaölkonzentration von $22 \%$ bzw. $7 \%(\mathrm{w} / \mathrm{v})$ ergab 7,52 $\mathrm{g} \mathrm{L}^{-1}$ Mannosylerythritollipid im Schüttelkolben und $21,5 \mathrm{~g} \mathrm{~L}^{-1}$ Mannosylerythritollipid im Fermenter. Die Struktur und die funktionellen Gruppen der Mannosylerythritollipid wurden durch Fourier-TransformationsInfrarotspektrometrie (FT-IR), Flüssigchromatographie-Massenspektrometrie (LC/MS) und ${ }^{1} \mathrm{H}$ - und ${ }^{13} \mathrm{C}$-Kernspinresonanzanalyse ('HNMR und ${ }^{13} \mathrm{C}-\mathrm{NMR}$ ) bestätigt. Tensideigenschaften der Mannosylerythritollipide, wie Oberflächenspannung, kritische Mizellenbildungskonzentration, Schaumbildung und Emulgierung wurden ebenfalls untersucht.

Stichwörter: Biotensid, Fermentation, Mannosylerythritollipide (MEL), Pseudozyma antarctica, Süßwasser

\section{Introduction}

Surfactants are amphiphilic surface-active agents consisting of both hydrophobic (tail) and hydrophilic (head) groups. The hydrophilic group consists of amino acid, peptide, carbohydrate, phosphate, alcohol or carboxylic acid and the hydrophobic moiety include saturated or unsaturated hydrocarbon chains of fatty acids. The surfactant character of molecules is due to their mixed hydrophilic and hydrophobic nature. The surfactants assist in reducing the surface tension and interfacial tension by accumulating and decreasing the intermolecular forces between two immiscible liquids or a liquid and a solid, thus allowing them to mix and disperse readily in water or other liquids $[1,2]$. The total annual worldwide production demand of surfactants is expected to rise over 24 million tons by 2020 [3]. Surfactants are majorly used in household and laundry detergents, along with applications in chemical, textile, cosmetics and personal care, food, health care and agriculture industry [4]. However, the growing awareness of the harmful environmental effects caused by the incomplete degradation of some surfactants released majorly from household applications has led to the increasing interest in the use of microbial-derived biosurfactants as an alternative to the conventional petroleum-derived chemical surfactants $[5,6]$. Moreover, the matters of sustainability, economic viability and need for the use of renewable resources as substrates have led to the turn from chemical surfactants to biosurfactants [3].

Microorganisms produce various primary and secondary metabolites during the different phases of their growth. Some of these metabolites, known as biosurfactants, produced by certain bacteria, yeast and fungi have been reported to reduce surface and interfacial tension [7]. Of the various known biosurfactants, glycolipids have a significantly increased potential for commercial applications due to their properties such as their high microbial productivity, good environmental compatibility and excellent functionality $[4,8-10]$. Among the glycolipids reported so far, sophorolipids are produced at a commercially viable yield of $300 \mathrm{~g} \mathrm{~L}^{-1}$ from the yeast Candida bombicola. Thus, the search for other microbial glycolipids with high productivity is of particular interest. Mannosylerythritol lipids (MEL) are glycolipids produced in high concentrations by the non-pathogenic yeast Pseudozyma antarctica unlike rhamnolipids, which are synthesized in high yields by the pathogenic bacteria Pseudomonas aeruginosa. In addition, the excellent bio- 
chemical functions, low toxicity, biodegradability, biocompatibility, surface activity and high antimicrobial activity makes MEL an attractive compound for commercial production and use $[4,5,11,12]$. As shown in Fig. 1, MEL is structurally composed of two parts, a 4-O- $\beta$-D-mannopyranosylD-erythritol hydrophilic moiety and a hydrophobic group consisting of a mixture of $\mathrm{C}_{6}-\mathrm{C}_{18}$ fatty acyl chains at the $\mathrm{C}^{\prime}$ and $\mathrm{C}^{\prime}$ ' of the mannose moiety. In addition, MEL possesses one or two acetyl groups at the $\mathrm{C4}^{\prime}$ and/or $\mathrm{C6}^{\prime}$ of the mannose moiety depending on the microorganism and the substrate used. Depending on the degree of acetylation at C4' and C6', MEL is classified as MEL-A, MEL-B, MEL-C and MEL-D. MEL-A is diacetylated, while MEL-B and MEL$\mathrm{C}$ are monoacetylated at $\mathrm{C6}^{\prime}$ and $\mathrm{C}^{\prime}{ }^{\prime}$ respectively. The completely deacetylated structure is MEL-D [13, 14].

MEL is produced by various yeast strains belonging to the genus Pseudozyma. The MEL producing species are P. antarctica, $P$. aphidis, $P$. crassa, $P$. fusiformata, $P$. graminicola, $P$. parantarctica, $P$. rugulosa, $P$. shanxiensis, $P$. siamensis and $P$. tsukubaensis. Based on the carbon sources present, different microbes synthesize a different type of MEL. Of all the species presented, P. antarctica synthesized the highest yield of MEL of $140 \mathrm{~g} \mathrm{~L}^{-1}$ while the fungal species of Ustilago produced MEL in low amounts [15].

MEL is considered as a multifunctional molecule with a broad range of industrial applications, such as tertiary oil recovery, decontamination of oily areas, crop protection and cosmetics, due to better biocompatibility and good microbial degradability [16, 17]. In addition, MEL possesses versatile biochemical actions such as antitumor and anticancer activities owing to their cell differentiation-inducing ability in cell lines such as human promyelocytic leukaemia HL60, rat pheochromocytoma and mouse melanoma cells [15, 16, 18, 19]. Morita et al. [18] recently reported the ceramide-like skincare and hair care properties making MEL a potential molecule in the formulation of anti-wrinkle and moisturizing skin cosmetics, skin foundations and hair care products. They also increase the efficiency of gene transfection mediated by cationic liposomes by membrane fusion [16].

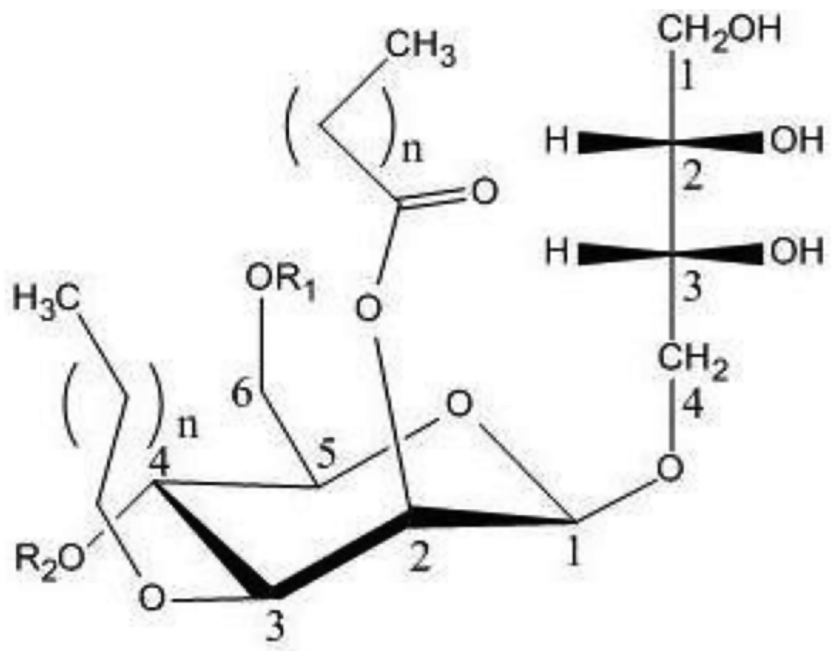

Figure 1 Chemical structure of mannosylerythritol lipids; MEL-A: $\mathrm{R}_{1}=\mathrm{R}_{2}=\mathrm{Ac} ; \mathrm{MEL}-\mathrm{B}: \mathrm{R}_{1}=\mathrm{Ac}, \mathrm{R}_{2}=\mathrm{H} ; \mathrm{MEL}-\mathrm{C}: \mathrm{R}_{1}=\mathrm{H}_{1} \mathrm{R}_{2}=\mathrm{Ac} ; \mathrm{MEL}-\mathrm{D}$ : $\mathrm{R}_{1}=\mathrm{R}_{2}=\mathrm{H} ; \mathrm{n}=6-10[17]$
Nowadays, a number of companies have commercialized biosurfactants [20]. The cost of rhamnolipids with $90 \%$ purity is around $\$ 1250 \mathrm{~kg}^{-1}$ whereas high purity synthetic surfactants, such as $99 \%$ (SDS), cost between $\$ 10$ and $\$ 20 \mathrm{~kg}^{-1}$. Thus, the high production cost is still one of the critical factors hampering the commercial applications of biosurfactants [21]. Designing a process to maximize the production while reducing the process cost will further benefit the commercial growth of biosurfactants. The raw material cost makes up to $30 \%$ of the total production cost, whereas the downstream processing accounts for about $60 \%$ of the cost [22]. Carbon sources are important for MEL production and are one of the high cost absorbing factors. MEL is one of the glycolipid biosurfactants produced by utilizing numerous renewable substrates such as soybean oil, palm oil, safflower oil, cottonseed oil, coconut oil, glucose, honey, and so on [23]. To reduce the raw material costs, MEL can also be produced using renewable waste resources such as waste cooking oil, oil refinery waste, distillery and whey wastes, potato process effluent, soapstock, agro-industrial waste and byproducts [22-24]. Hence, the use of waste streams as substrates is recommended to reduce the production cost [25].

Glycerol is used in various applications in automotive, cosmetic, food, paint, tobacco, pharmaceutical, pulp and paper, leather and textile industries and is is also considered as a potential feedstock for new industrial fermentations in the future [26]. Sweetwater, a by-product, obtained from the continuous and batch autoclave processes of the commercial fatsplitting plants contains about 10\%-20\% glycerol with little or no mineral acids and salts as compared to the spent lye from kettle soapmaking. The fatty acids that rise to the top of the sweetwater after the splitting process are removed by skimming. Then, a small amount of alkali is added to precipitate the dissolved fatty acids and neutralize the liquor which is then filtered [27, 28]. This inexpensive by-product containing glycerol has good availability for commercial purpose at lower cost and can be used as an alternative to the conventional hydrophilic carbon substrates like glucose, sucrose, refined glycerol, etc. In addition, large amount of inexpensive glycerol is expected to be available at lower cost from biodiesel plants owing to the increasing need for renewable fuels and the demand and production of biodiesel throughout the world [26, 29]. Furthermore, as glycerol can be used as a carbon feedstock in industrial microbiology, this by-product adds value to the productive chain of the biodiesel industry, contributing to their competitiveness [26]. Glycerol as well as sweetwater have been used for the production of various biosurfactants such as rhamolipids and sophorolipids [22, 26, 27, 29]. The low cost glycerol in the form of sweetwater can thus be considered as a potential alternative for the production of MEL [27].

Furthermore, apart from the expenses for raw materials and investment costs, downstream processing is the highest cost absorbing factor in biosurfactants production. As the industrial demand for biosurfactants is constantly growing, it is essential to recover and purify the biosurfactants in a cost-effective manner to reduce the overall cost of production. However, for some applications, this purity grade will not be necessary and thus purification costs should be more moderate [30].

The current study explores the use of sweetwater as a waste carbon source in combination with soybean oil for MEL production using Pseudozyma antarctica (MTCC 2706) to reduce the raw material cost. The study also focuses on 
reducing the use of solvents in the downstream processing of crude MEL by the one-solvent heating method. Furthermore, the surfactant and antimicrobial properties of the synthesized MEL are also studied.

\section{Experimental procedure}

\subsection{Substrates and chemicals}

Sweetwater was obtained as a gift sample from VVF Ltd., Mumbai. The glycerol content was determined by the sodium-periodate oxidation method as per the AOCS method Ea 6-51 [31]. The sweetwater was found to contain $10.6 \%$ (w/v) glycerol. Refined soybean oil was procured from the local market. All other chemicals were of analytical grade and were procured from S D Fine-Chem Ltd., Mumbai.

\subsection{Microorganism}

The mannosylerythritol lipids producing strain Pseudozyma antarctica (MTCC 2706) was procured from Microbial Type Culture Collection and Gene Bank (MTCC), Institute of Microbial Technology, Chandigarh (India), as MTCC 2706.

\subsection{Microorganism and culture conditions}

Stock cultures of Pseudozyma antarctica (MTCC 2706) were cultivated for 2 days at $30{ }^{\circ} \mathrm{C}(200 \mathrm{rpm})$ on yeast malt agar medium containing $1 \%$ glucose, $0.3 \%$ malt extract, $0.3 \%$ yeast extract and $0.5 \%$ peptone. They were stored at $4{ }^{\circ} \mathrm{C}$ and renewed every 2 weeks. Seed cultures were prepared by inoculating cells grown on slants into $250 \mathrm{~mL}$ Erlenmeyer flask containing $50 \mathrm{~mL}$ of growth medium (4\% glucose, $0.3 \% \mathrm{NaNO}_{3}, 0.03 \% \mathrm{KH}_{2} \mathrm{PO}_{4}, 0.03 \% \mathrm{MgSO}_{4}$ and $0.1 \%$ yeast extract) at $30^{\circ} \mathrm{C}, 200 \mathrm{rpm}$ for 2 days (pH 6.0) [32, 33].

\subsection{Effect of hydrophobic and hydrophilic carbon sources on MEL production}

To study the influence of soybean oil on MEL formation, the concentrations of all other media components were kept constant [34]. The different concentrations of soybean oil selected for the study were $6 \%, 7 \%, 8 \%$ and $9 \%$ w/v. Similarly, the different concentrations selected to study the impact of sweetwater were $16 \%, 18 \%, 20 \%, 22 \%$ and $24 \%$ w/v. All the other media components including the selected soybean oil concentration were kept constant.

\subsection{Shake flask fermentation}

Fermentation was carried out in a $250 \mathrm{~mL}$ Erlenmeyer flask by inoculating $2 \% \mathrm{v} / \mathrm{v}$ seed culture in $50 \mathrm{~mL}$ of production medium $\left(0.3 \% \mathrm{NaNO}_{3}, 0.03 \% \mathrm{KH}_{2} \mathrm{PO}_{4}, 0.03 \% \mathrm{MgSO}_{4}\right.$ and $0.1 \%$ yeast extract) ( $\mathrm{pH} 6.0$ ) with varying amounts of soybean oil (6\% to $9 \%$ ) and sweetwater (16\% to $24 \%$ ), followed by cultivation at $30{ }^{\circ} \mathrm{C}$ for 7 days at $200 \mathrm{rpm}$ in an incubator shaker [22].

\subsection{Bioreactor studies}

The bioreactor production of MEL was carried out in a $5 \mathrm{~L}$ (working volume $3 \mathrm{~L}$ ) jar fermenter (Eppendorf fermenter,
Germany). Fermentation was carried out by inoculating $2 \%$ $\mathrm{v} / \mathrm{v}$ seed culture in $3 \mathrm{~L}$ of production medium (7\% soybean oil, $22 \%$ sweetwater, $0.3 \% \mathrm{NaNO}_{3}, 0.03 \% \mathrm{MgSO}_{4}, 0.03 \%$ $\mathrm{KH}_{2} \mathrm{PO}_{4}$ and $0.1 \%$ yeast extract) operated for 7 days. The fermenter was operated at $600 \mathrm{rpm}$ with an aeration rate of 1 vvm. The temperature of the vessel was controlled at $30{ }^{\circ} \mathrm{C}$ by the heating jacket and the $\mathrm{pH}$ was maintained at pH 6.0 [35].

\subsection{Solvent extraction method}

The MEL was extracted by solvent extraction as described by Bhangale et al. [17]. After completion of fermentation, the $\mathrm{pH}$ of the cell culture was adjusted to 2.0 using $1 \mathrm{~N} \mathrm{HCl} \mathrm{so-}$ lution. The broth was then washed with hexane $(1: 1)$ to remove unconsumed oil. The aqueous phase was washed with ethyl acetate $(1: 1)$ to extract MEL. The ethyl acetate washings were then evaporated under vacuum and the MEL in the round bottom flask was weighed.

\subsection{One-solvent heating method}

The extraction of MEL from the cell culture was performed as described by Rau et al. [36] with slight modifications. Briefly, the cell suspension was washed with hexane to remove residual oil and then heated at $121{ }^{\circ} \mathrm{C}$ for $20 \mathrm{~min}$. After heating, a sticky thick liquid and an aqueous phase was formed. The MEL was present in the thick liquid phase which was separated by pouring off the cell debris containing aqueous phase.

\subsection{Purification of crude MEL}

The crude MEL was purified by silica-gel column chromatography as described by Fukuoka et al. [37]. Briefly, $5 \mathrm{~g}$ of crude MEL was dissolved in $5 \mathrm{~mL}$ chloroform and fractionated on a glass column $(1.8 \mathrm{~cm} \times 30 \mathrm{~cm})$ loaded with silica gel. It was then purified using a gradient elution of chloroform/acetone mixtures $(10: 0$ to $0: 10, \mathrm{v} / \mathrm{v})$ as the solvent system. The eluted fractions of each ratio were then combined and evaporated to obtain the purified MEL.

\subsection{Analysis of biomass, residual substrate and MEL content}

Approximately $1 \mathrm{~mL}$ of the broth solution was centrifuged at $8000 \mathrm{rpm}$ for $15 \mathrm{~min}$ and the cells were re-suspended in $3 \mathrm{~mL}$ distilled water. The biomass was measured at $580 \mathrm{~nm}$ and calibrated using dry weight by drying at $100^{\circ} \mathrm{C}$ until constant weight [22]. For residual substrate analysis, $1 \mathrm{~mL}$ of the broth solution was centrifuged at $8000 \mathrm{rpm}$ for $15 \mathrm{~min}$ and the cell-free supernatant was collected and washed with hexane to remove residual oil. The aqueous layer was diluted and the free glycerol content in the sweetwater was determined by sodium-periodate oxidation method [31]. The hexane extracts were combined to determine the residual oil content gravimetrically [22].

To analyze the MEL content, $1 \mathrm{~mL}$ of broth solution was centrifuged for $15 \mathrm{~min}$ at $8000 \mathrm{rpm}$. The cell-free supernatant was washed with ethyl acetate and centrifuged for $15 \mathrm{~min}$ at $8000 \mathrm{rpm}$. The ethyl acetate washings were collected, quantitatively diluted to $10 \mathrm{~mL}$, and evaporated under vacuum. The obtained residue was dissolved in $5 \mathrm{~mL}$ distilled water after 
cooling to room temperature and the MEL concentration was determined by the anthrone method [38]. Standards, blanks and unknowns were analyzed in triplicate [22].

\subsection{Characterization of MEL}

The formation of MEL was confirmed by TLC on silica gel plates using a solvent system of chloroform : methanol : water $(65: 15: 2, \mathrm{v} / \mathrm{v} / \mathrm{v})$. The spots were visualized by spraying the plate with chloroform : methanol $(50: 50, \mathrm{v} / \mathrm{v})$ visualization agent and heating it in a hot air oven at $105^{\circ} \mathrm{C}$ for 5 min [17]. The analysis of the functional groups of MEL was done using FTIR spectroscopy. The FTIR spectrum was recorded on a Shimadzu 8400S FTIR spectrometer for the liquid sample. For the analysis, a scanning range of $4000 \mathrm{~cm}^{-1}-400 \mathrm{~cm}^{-1}$ was used for 45 repeated scans. All the spectra were recorded with transmission mode [22].

The MEL purified by column chromatography was used for LC-MS analysis. The LC-MS of the sample was carried out by Shobhaben Pratapbhai Patel School of Pharmacy \& Technology Management (SPPSPTM), SVKM, NMIMS, Mumbai, Maharashtra, India. The Shimadzu 8040 was equipped with ESI and Triple Quadrupole MS spectrometer. A $3.9 \mathrm{~mm} \times 300 \mathrm{~mm}(10 \mu \mathrm{m})$ Waters Bondapak C18 column was used. The mobile phase consisted of solvent A (isopropanol) and solvent B (acetonitrile). The elution was

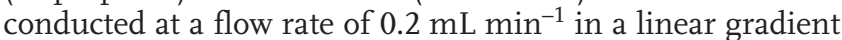
as follows: solvent A from $10 \%$ to $30 \%$ within 10 min and then to $100 \%$ within $55 \mathrm{~min}$. The ionization parameters were adapted to the flow rate and the mass range (2001500). A drying temperature of $325^{\circ} \mathrm{C}$ was applied together with a drying gas $\left(\mathrm{N}_{2}\right)$ at a flow of $10 \mathrm{~mL} \mathrm{~min}{ }^{-1}$, a capillary voltage of $2.5 \mathrm{kV}$, a corona voltage of $4 \mathrm{kV}$, and a nebulizer pressure of 35 psi $(241.32 \mathrm{kPa})$. The injection volume was $5 \mu \mathrm{L}[39]$.

The detailed structure of the purified MEL was analyzed by ${ }^{1} \mathrm{H}$ - and ${ }^{13} \mathrm{C}-\mathrm{NMR}$ with an Agilent $400 \mathrm{MHz}$ NMR system at $30{ }^{\circ} \mathrm{C}$. NMR was carried out by dissolving $\approx 30 \mathrm{mg}$ of purified MEL in $700 \mu \mathrm{L}$ of deuterated chloroform $\left(\mathrm{CDCl}_{3}\right)$. The coupling constants were measured in Hertz $(\mathrm{Hz})$ and the chemical shifts $\left(\delta^{1} \mathrm{H}, \delta^{13} \mathrm{C}\right)$ were expressed as ppm, which were related to tetramethylsilane (TMS, $\delta-0)[40,41]$.

\subsection{Testing of surfactant properties}

The surface tension of MEL in distilled water was determined at room temperature using K-100 Krüss tensiometer applying the Wilhelmy plate method [25]. MEL solution of $0.1 \%(\mathrm{w} / \mathrm{v})$ concentration was used as the stock solution for CMC measurement. Dilutions of $5 \mathrm{mg} \mathrm{L}^{-1}-100 \mathrm{mg} \mathrm{L}^{-1}$ were prepared by adding a specific amount of stock solution in distilled water and the surface tension was measured at each dilution. The CMC of the surfactant was determined by plotting a graph of surface tension versus the log of concentration [25].

The foaming properties of $0.1 \%(\mathrm{w} / \mathrm{v})$ MEL were determined using the Ross-Miles apparatus. The foam height was measured at specific time intervals of $5 \mathrm{~min}$ for $30 \mathrm{~min}$ [42]. The emulsification property of MEL was assessed as described by Subrahmanyam and Achaya [43] using light liquid paraffin. An equal volume $(5 \mathrm{~mL})$ of liquid paraffin and $0.5 \%(\mathrm{w} / \mathrm{v})$ MEL solution was mixed by vortex mixing for
$1 \mathrm{~min}$ at $2000 \mathrm{rpm}$ and room temperature. After mixing, the time required to separate the two phases was recorded. All the measurements were taken in duplicate.

\subsection{Antimicrobial activity of crude MEL}

The antimicrobial activity of MEL was determined by the cup-plate method using Staphylococcus aureus (DSM 3463) as described by Sudha et al. [44]. The zone of inhibition (ZOI) was measured in $\mathrm{mm}$ in triplicate.

\section{Results}

\subsection{Effect of hydrophobic and hydrophilic carbon sources on MEL production}

The maximum concentration of soybean oil was found to be $7 \%(\mathrm{w} / \mathrm{v})$ which gave the highest MEL yield of $2.88 \mathrm{~g} \mathrm{~L}^{-1}$. As shown in Fig. 2, the yield increased significantly with an increase in soybean oil concentration up to $7 \%(\mathrm{w} / \mathrm{v})$ and any further increase caused the yield to slightly decrease.

In addition, $7 \%(\mathrm{w} / \mathrm{v})$ soybean oil was used as the hydrophobic source and the concentration of sweetwater as hydrophilic substrate was varied. Out of the different concentrations studied, $22 \%$ (w/v) sweetwater concentration gave the highest yield of $7.52 \mathrm{~g} \mathrm{~L}^{-1}$ as shown in Fig. 3.

\subsection{Bioreactor studies}

While the production of MEL from $P$. antarctica in shaking flasks was reported in detail, only limited experiments were undertaken in larger bioreactors [13, 36, 45, 46]. The yield of MEL in larger bioreactors was $21.5 \mathrm{~g} \mathrm{~L}^{-1}$, which is 2.74 times higher than the yield in shaking flasks.

\subsection{Extraction of crude MEL}

The extraction of MEL using solvents was compared with the one-solvent heating method. Both methods extracted similar amounts of MEL from the culture broth.

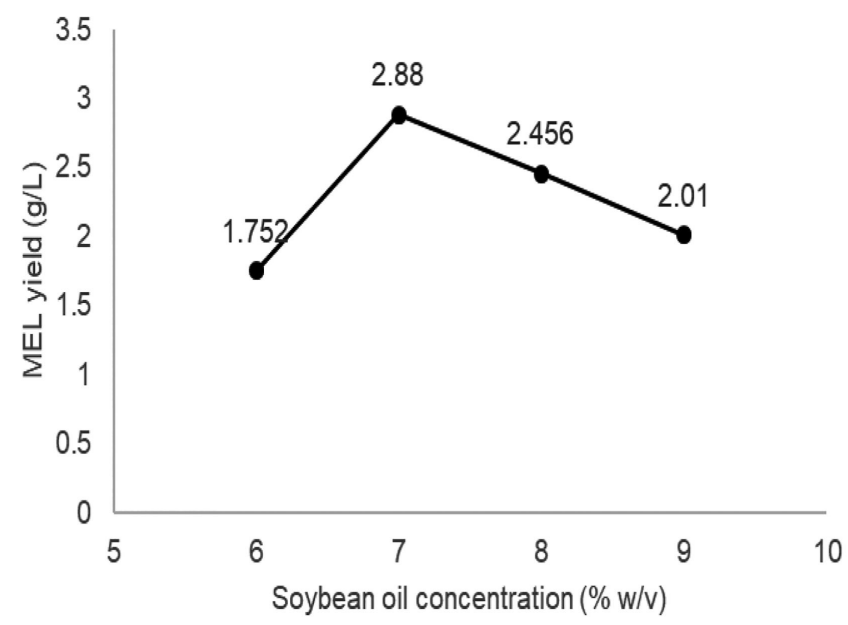

Figure 2 Effect of soybean oil concentration on the production of mannosylerythritol lipids by Pseudozyma antarctica (MTCC 2706) in a shake flask at $30^{\circ} \mathrm{C}, 200 \mathrm{rpm}$ for 7 days 


\subsection{Purification of MEL}

The crude MEL extracted from the culture broth after 7 days was purified by silica-gel column chromatography. The purified fraction of MEL was mainly eluted with chloroform : acetone $(8: 2, \mathrm{v} / \mathrm{v})$. From $5 \mathrm{~g}$ of crude MEL $2.37 \mathrm{~g}$ of purified MEL was obtained. The fractions of purified MEL were collected, combined and the solvent was evaporated using a rotary vacuum evaporator to obtain the purified MEL.

\subsection{Biomass, residual substrate and MEL content analysis}

The biomass consumption, substrate uptake and MEL production over the 7-day fermentation cycleare are shown in Fig. 4. The MEL production profile over the 7-day time course was found consistent with earlier studies [17, 47, 48]. The cell growth increased during the fermentation pro-

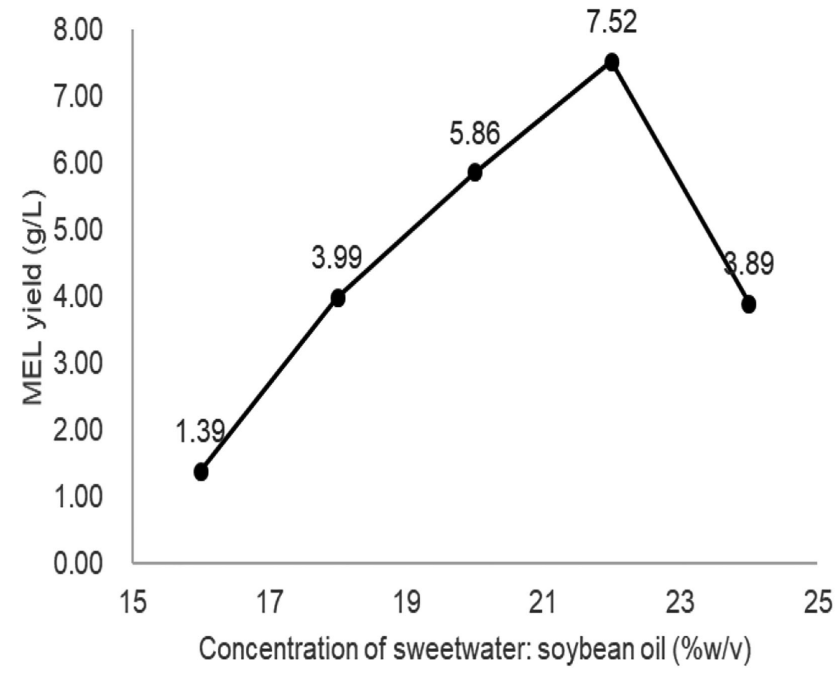

Figure 3 Effect of sweetwater concentration on mannosylerythritol lipid production by Pseudozyma antarctica (MTCC 2706) at shake flask level at $30^{\circ} \mathrm{C}$ $200 \mathrm{rpm}$ for 7 days

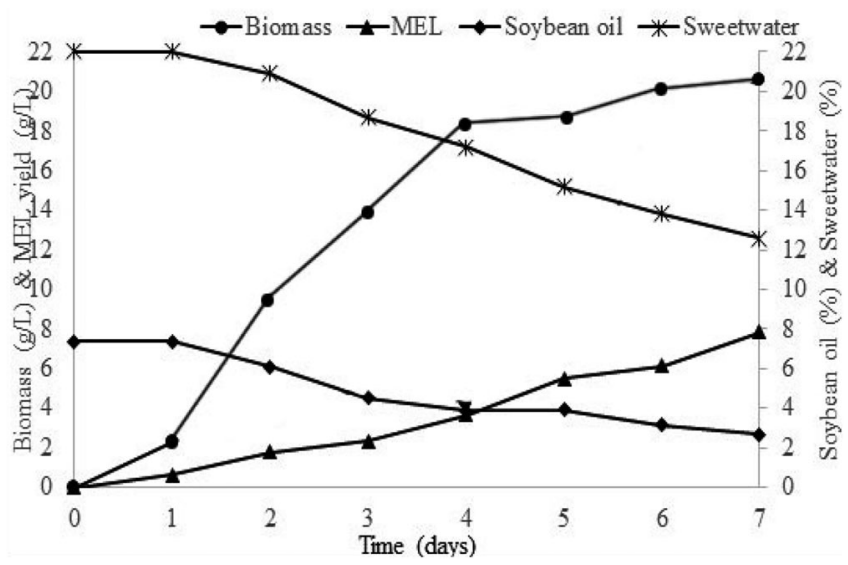

Figure 4 Time course of cell growth, soybean oil and sweetwater consumption and mannosylerythritol lipids production by $P$. antarctica using $7 \% \mathrm{w} / \mathrm{V}$ soybean oil and $22 \% \mathrm{w} / \mathrm{v}$ sweetwater during 7-day shake flask submerged fermentation at $30^{\circ} \mathrm{C}$, $200 \mathrm{rpm}$ cess. There was no significant MEL production in the lag phase, however, the formation increased slowly during the exponential phase up to 3 days and then increased rapidly from day 4 to day 7 during the stationary phase.

\subsection{Analytical detection of MEL}

The formation of MEL obtained after fermentation was confirmed by thin layer chromatography as shown in Fig. 5. The $R_{f}$ of residual soybean oil was 0.88 and the $R_{f}$ of MEL was found to be 0.58 . The FTIR spectrum of the purified MEL is shown in Fig. 6 and it is similar to the spectrum reported by Patil et al. [22]. The structure of incorporated fatty acids in the purified MEL was analyzed by LC-MS. Table 1 summarizes the list of all detected and identified masses of fatty acid chains in the purified MEL sample. The structure of purified MEL was confirmed by ${ }^{1} \mathrm{H}$ and ${ }^{13} \mathrm{C}$ NMR which showed similar structural patterns to those already reported $[17,32,37,40,46,49-53]$. Table 2 represents the ${ }^{1} \mathrm{H}$ and

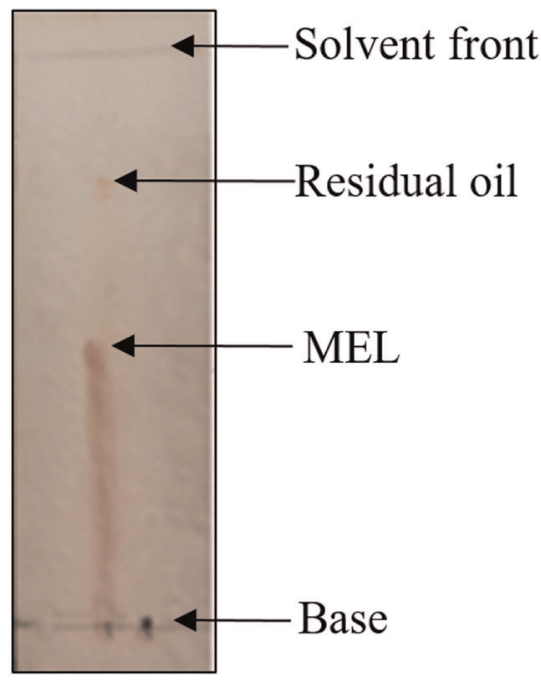

Figure 5 TLC of extracted mannosylerythritol lipids using a solvent system of chloroform : methanol : water $(65: 15: 2, \mathrm{v} / \mathrm{v} / \mathrm{v})$. The spots were visualized with chloroform : methanol $(50: 50, \mathrm{v} / \mathrm{v})$ visualization agent

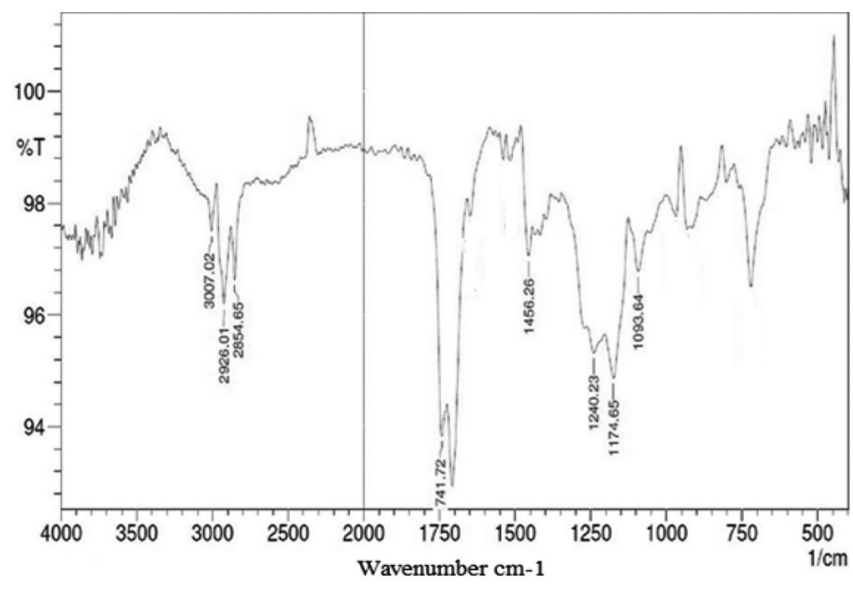

Figure 6 FTIR spectrum of mannosylerythritol lipids produced by $P$. antarctica (MTCC 2706) 
${ }^{13} \mathrm{C}$ NMR chemical shifting of D-mannose, meso-erythritol, acetyl, and fatty acid groups of MEL.

\subsection{Surfactant properties of MEL}

The surface tension studies showed that MEL reduced the surface tension of water better than the reference surfactant Tween 80. MEL effectively reduced the surface tension of water from $70.52 \mathrm{mN} \mathrm{m}^{-1}$ to $33.53 \mathrm{mN} \mathrm{m}^{-1}$ while Tween 80 reduced the surface tension of water from $70.38 \mathrm{mN} \mathrm{m}^{-1}$ to $38.21 \mathrm{mN} \mathrm{m}^{-1}$. As shown in Fig. 7, the CMC of the extracted MEL was $55 \mathrm{mg} \mathrm{L}^{-1}\left(8 \times 10^{-5} \mathrm{~mol} \mathrm{~L}^{-1}\right)$ and the surface tension of water at the CMC was $30.2 \mathrm{mN} \mathrm{m}^{-1}$.

The foaming studies showed that the foam height of the reference polysorbate 80 was much higher than that of MEL. The initial foam height of polysorbate 80 was $65 \mathrm{~mm}$ whereas the foam height of MEL was observed to be only $10 \mathrm{~mm}$. The emulsifying ability of MEL was studied against liquid paraffin. The emulsification properties of MEL and polysorbate 80 presented in Fig. 8 show that MEL is as effective as polysorbate 80 in emulsification. The emulsifying ability as well as the stability of the emulsion formed by MEL was comparable to that of polysorbate 80 .

\subsubsection{Antimicrobial activity of MEL}

Figure 9 shows the antimicrobial activity of MEL with a ZOI of $13 \mathrm{~mm}$ against $S$. aureus.

\section{Discussion}

\subsection{Effect of hydrophobic carbon source on MEL production}

Table 3 shows the physicochemical properties of soybean oil evaluated according to the AOCS official methods of analysis [54]. It has been reported by Beck et al. and Yu et al. that the carbon chain length and saturation variability of the hydrophobic substrate influences the number of acylation and the length of unsaturated carbon chain of MEL during its production $[14,55]$. The analysis of fatty acids by gas chro- matography revealed that soybean oil contains both saturated $(16: 0,18: 0)$ and unsaturated $(18: 2,18: 3)$ fatty acids with linoleic acid and oleic acid as the most abundant fatty acids. The moderate iodine value obtained indicated the presence of unsaturated carbon chains in the soybean oil [56]. Furthermore, a number of hydrophobic carbon sources have been utilized such as hexoses, pentoses, soluble starch, sugar alcohols, fatty acids and triglycerides [19]. Of these, vegetable oils have been considered to be the most suitable carbon source for MEL synthesis [19]. Among all the vegetable oils used so far (soybean oil, safflower oil, olive oil, corn oil, palm oil, etc), soybean oil has been found to be the best hydrophobic carbon source for MEL production [13, 14]. Thus, considering the fatty acid profile and presence of unsaturated carbon chains, soybean oil was considered as a potential carbon source for the production of MEL [23].

To study the effect of the hydrophobic substrate on MEL production, different concentrations of soybean oil suitable for MEL formation were analyzed. The various concentrations considered for the study were: $6 \%, 7 \%, 8 \%$ and $9 \%$ $(\mathrm{w} / \mathrm{v})$. The low yield of MEL observed at low soybean oil concentrations may possibly be because the hydrophobic part (fatty acid chain) of the MEL needs to be synthesized denovo in the absence of hydrophobic substrate while lower concentrations would be utilized for cell growth with lesser fatty acid chains for MEL production. Whereas, higher concentrations would not be completely utilized by the organism due to substrate inhibitory effect thus, $7 \%$ (w/v) soybean oil was selected for further studies [23].

\subsection{Effect of hydrophilic carbon source on MEL production}

Sweetwater is a waste by-product from the fat-splitting industry produced in large quantities and is thus easily available. Sweetwater is a by-product consisting of $10 \%-20 \%$ glycerol in water [57]. The analysis of sweetwater is shown in Table 4 [58]. The sweetwater contained $10.6 \%$ glycerol and was used as hydrophilic carbon source without any purification. The use of refined glycerol to produce MEL by fermentation has previously been reported by Patil et al. [22]. Table 5 represents the various hydrophilic substrates utilized

\begin{tabular}{|c|c|c|c|}
\hline $\mathrm{m} / \mathrm{z}$ & molecular mass/g mol${ }^{-1}$ & fatty acid chain & relative intensity \\
\hline 638.40 & 615.4 & $\mathrm{C} 8: 0-\mathrm{C} 8: 0$ & 32.44 \\
\hline 660.40 & 637.4 & $\mathrm{C} 8: 1-\mathrm{C} 10: 2$ & 6.25 \\
\hline 662.30 & 639.3 & $\mathrm{C} 8: 0-\mathrm{C} 10: 2$ & 9.68 \\
\hline 676.40 & 653.4 & $\mathrm{C} 8: 0-\mathrm{C} 10: 0$ & 11.90 \\
\hline 705.30 & 682.3 & $\mathrm{C} 12: 2-\mathrm{C} 12: 2$ & 8.56 \\
\hline 706.50 & 683.5 & $\mathrm{C} 10: 2-\mathrm{C} 14: 2$ & 55.0 \\
\hline 707.40 & 684.4 & $\mathrm{C} 12: 1-\mathrm{C} 12: 2 / \mathrm{C} 10: 1-\mathrm{C} 14: 2$ & 23.51 \\
\hline 708.45 & 685.45 & $\mathrm{C} 12: 1-\mathrm{C} 12: 1 / \mathrm{C} 12: 0-\mathrm{C} 12: 2 / \mathrm{C} 10: 0-\mathrm{C} 14: 2$ & 17.50 \\
\hline 724.30 & 701.3 & $\mathrm{C} 8: 1-\mathrm{C} 14: 0$ & 8.74 \\
\hline 732.45 & 709.45 & $\mathrm{C} 10: 0-\mathrm{C} 12: 0 / \mathrm{C} 8: 0-\mathrm{C} 14: 0$ & 26.52 \\
\hline 866.45 & 843.45 & $\mathrm{C} 16: 3-\mathrm{C} 16: 2$ & 9.48 \\
\hline
\end{tabular}

Table 1 Fatty acid contents of purified mannosylerythritol lipids detected by LC-MS 
for MEL production. To study the utilization of sweetwater as the hydrophilic carbon source, the glycerol content of the culture broth was analyzed. The analysis showed that glycerol was converted to mannosyl and erythritol sugar which, in turn, was utilized by the yeast cells for the production of secondary metabolite as MEL. Thus, sweetwater can be efficiently used as a hydrophilic substrate for MEL synthesis to reduce raw material cost as well as streamline the waste into value-added product.

Lower concentrations of sweetwater affected the biomass concentrations due to insufficient availability of the hydrophilic carbon source in the media, while any increase in sweetwater concentration above $22 \%$ (w/v) slightly reduced the MEL yield. The reduction in yield with further increase in sweetwater concentration is expected to be due to insufficient hydrophobic substrate at higher sweetwater levels or substrate inhibitory effect [23]. Furthermore, sweetwater used in combination with soybean oil gave a better yield than soybean oil alone which was similar to the results reported previously in the literature $[17,22,32,33,41]$. This indicated that the production of MEL was not growth associated and it depends on the type and chemical nature of the carbon sources used as evident from the work described by Patil et al. [22]. In addition, the time course profile in Fig. 4 clearly shows that $P$. antarctica can utilize both the carbohydrate and the lipid content from the media to grow

\begin{tabular}{|c|c|c|c|c|}
\hline Functional group & Multiplicity & $\delta^{1} \mathrm{H} / \mathrm{ppm}$ & Functional group & $\delta^{13} \mathrm{C} / \mathrm{ppm}$ \\
\hline Sugar & & & Sugar & \\
\hline D-mannose & & & D-mannose & \\
\hline $\mathrm{H}-1$ & Doublet & 4.74 & $C-1$ & 99.2 \\
\hline $\mathrm{H}-2$ & Doublet & 5.4 & $C-2$ & 68.87 \\
\hline $\mathrm{H}-3$ & Doublet of doublet & 5.23 & $C-3$ & 71.8 \\
\hline $\mathrm{H}-4$ & Multiplet & 5.28 & $C-4$ & 65 \\
\hline $\mathrm{H}-5$ & Multiplet & 3.6 & $C-5$ & 75.13 \\
\hline H-6a & Doublet of doublet & 4.12 & $C-6$ & 62.07 \\
\hline $\mathrm{H}-6 \mathrm{~b}$ & Doublet of doublet & 4.28 & & \\
\hline Hydroxyls & Broad & $2.72 \sim 2.85$ & & \\
\hline meso-Erythritol & & & meso-Erythritol & \\
\hline $\mathrm{H}-1 \mathrm{a}^{\prime}$ & Multiplet & $3.54 \sim 3.72$ & $C-1^{\prime}$ & 63.6 \\
\hline$H-1 b^{\prime}$ & Multiplet & $3.54 \sim 3.72$ & $C-2^{\prime}$ & 71.1 \\
\hline $\mathrm{H}-2^{\prime}$ & Multiplet & $3.54 \sim 3.72$ & $C-3^{\prime}$ & 71.5 \\
\hline $\mathrm{H}-3^{\prime}$ & Multiplet & $3.54 \sim 3.60$ & $C-4^{\prime}$ & 72.38 \\
\hline $\mathrm{H}-4 \mathrm{a}^{\prime}$ & Doublet of doublet & 3.85 & & \\
\hline $\mathrm{H}-4 \mathrm{~b}^{\prime}$ & Doublet of doublet & 3.98 & & \\
\hline Hydroxyl & Broad & $2.72 \sim 2.85$ & & \\
\hline \multicolumn{5}{|l|}{ Acetyl } \\
\hline$-\mathrm{CH}_{3}$ & Singlet & 2.08 & & 22.52 \\
\hline$-C=O$ & & & & 172.81 \\
\hline \multicolumn{5}{|l|}{ Fatty acids } \\
\hline$-\mathrm{C}=\mathrm{O}(\mathrm{C}-2)$ & & & & 173.86 \\
\hline$-\mathrm{C}=\mathrm{O}(\mathrm{C}-3)$ & & & & 173.23 \\
\hline$-\mathrm{CH}_{3}$ & Broad & 0.88 & & 14.21 \\
\hline$-\mathrm{CO}-\mathrm{CH}_{2}-(\mathrm{C}-2)$ & Multiplet & 2.3 & & 34.15 \\
\hline$-\mathrm{CO}-\mathrm{CH}_{2}-(\mathrm{C}-3)$ & Multiplet & 2.34 & & 34.04 \\
\hline$-\mathrm{CO}-\mathrm{CH}_{2}-\mathrm{CH}_{2}-$ & Multiplet & $1.57 \sim 1.61$ & & 25.49 \\
\hline$-\left(\mathrm{CH}_{2}\right)_{\mathrm{n}^{-}}$ & Broad & $1.23 \sim 1.35$ & & $22.62 \sim 34.13$ \\
\hline$-\mathrm{CH}=\mathrm{CH}-$ & Multiplet & $5.23 \sim 5.40$ & & 127.71 \\
\hline$-\mathrm{CH}=\mathrm{CH}-\mathrm{CH}_{2}-$ & Multiplet & $1.96 \sim 2.05$ & & 25.59 \\
\hline
\end{tabular}

Table $2{ }^{1} \mathrm{H}$ and ${ }^{13} \mathrm{C}$ NMR chemical shift data of purified mannosylerythritol lipids in $\mathrm{CDCl}_{3}$ to determine the structure of MEL ( $\delta$ : Chemical shift in ppm) 
as well as to produce MEL, thus indicating its potential application in the utilization of the fat-splitting industry waste for the synthesis of MEL at a commercial level [25].

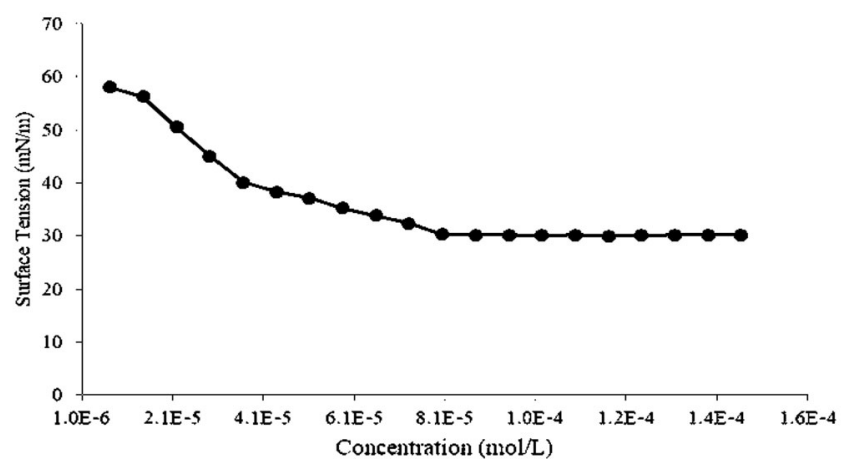

Figure 7 Variations in surface tension with logarithmic change in concentration of mannosylerythritol lipids synthesized by P. antarctica (MTCC 2706) to determine $\mathrm{CMC}$ of MEL

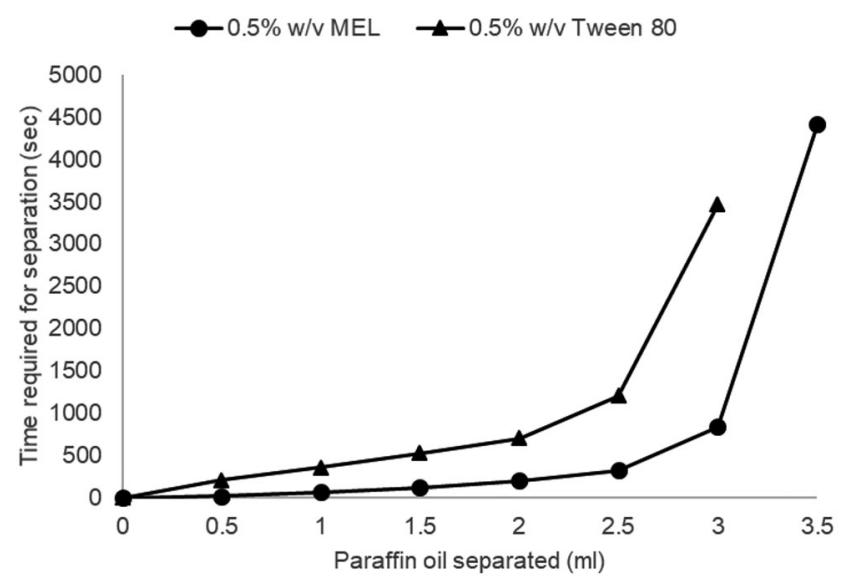

Figure 8 Emulsifying power and emulsion stability of mannosylerythritol lipid and polysorbate 80 at $0.5 \%(\mathrm{w} / \mathrm{v})$ surfactant concentration against liquid paraffin

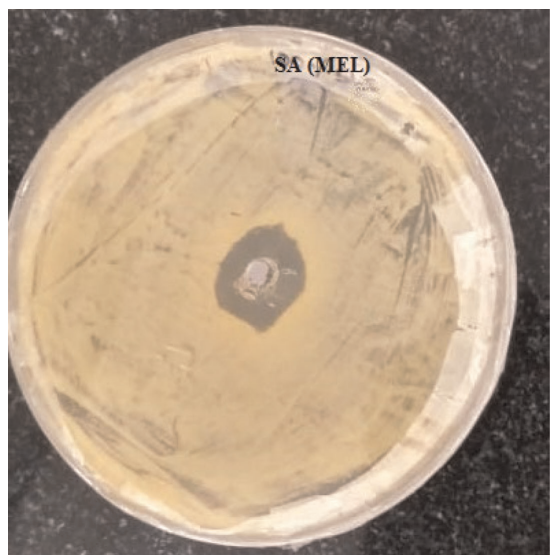

Figure 9 Antimicrobial activity of synthesized mannosylerythritol lipids against $S$. aureus with $\mathrm{ZOI}$ of $13 \mathrm{~mm}$
The use of industrial wastes as substrates will help to reduce the high cost of raw materials involved in biosurfactants production. Glucose, sucrose and glycerol are the hydrophilic substrates known to produce a higher yield of MEL. The current price of glucose, sucrose and glycerol is $0.8 \$ \mathrm{~kg}^{-1}, 0.6 \$ \mathrm{~kg}^{-1}$ and $1 \$ \mathrm{~kg}^{-1}$ respectively, whereas the cost of sweetwater is $0.14 \mathrm{~kg}^{-1}$, which is almost $60 \%-80 \%$ less than the cost of glucose, sucrose and glycerol. The use of sweetwater is very less expensive than that of other commonly used sugar sources which will thereby help in reducing the overall raw material cost of MEL synthesis [25].

\subsection{Bioreactor studies}

It has been reported that the yield of biosurfactants in the bioreactor can be increased to 3 to 6 times compared to the shaking flask [27]. Therefore, MEL production in the bioreactor was investigated to determine the increase in MEL production. The increase in yield at the bioreactor level was probably due to better control of operating conditions such as aeration, stirring, $\mathrm{pH}$ and temperature [25]. The MEL yield was further improved by optimizing media components and physical parameters such as temperature, $\mathrm{pH}$, agitation and aeration.

\subsection{Extraction of MEL}

In the extraction of MEL by heating described by Rau et al. [36], the amount of oil in the MEL extract was more as compared to that of the solvent extraction method. However, washing the culture broth with hexane before heating reduced the amount of residual oil in the product since the oil dissolved better in hexane. Thus, the one-solvent heating method can be efficiently used as an alternative extraction method to the conventional solvent extraction technique as it helps to reduce the use of 2 solvents without affecting the final product.

\begin{tabular}{|c|c|c|}
\hline Property & $\begin{array}{c}\text { AOCS } \\
\text { method of } \\
\text { analysis [54] }\end{array}$ & Value $^{\mathrm{a})}$ \\
\hline Acid value (mg KOH g-1) & Te-la-64 & $0.49 \pm 0.03$ \\
\hline Saponification value ( $\mathrm{mg} \mathrm{KOH} \mathrm{g}^{-1}$ ) & Tl-la-64 & $192.3 \pm 0.35$ \\
\hline lodine value $\left(\mathrm{mg} \mathrm{I}_{2} \mathrm{~g}^{-1}\right)$ & Tg-la-64 & $126 \pm 0.5$ \\
\hline Unsaponifiable matter (\%) & Tk la-64 & $1.5 \pm 0.5$ \\
\hline Peroxide value $\left(\mathrm{mEq} \mathrm{kg}{ }^{-1}\right)$ & Cd-8-53 & $9.2 \pm 0.35$ \\
\hline Viscosity $(\mathrm{CP})$ at $28^{\circ} \mathrm{C}$ & Ja-10-87 & $41.3 \pm 0.5$ \\
\hline Specific gravity $\left(28^{\circ} \mathrm{C}\right)\left(\mathrm{g} \mathrm{cm}^{-3}\right)$ & & $0.919 \pm 0.06$ \\
\hline Fatty acid composition (wt\%) & Ce-1-62 & \\
\hline Palmitic acid (C16:0) & & 9.36 \\
\hline Stearic acid (C18:0) & & 4.19 \\
\hline Oleic acid (C18: 1) & & 23.31 \\
\hline Linoleic acid (C18:2) & & 54.23 \\
\hline Linolenic acid (C18:3) & & 8.11 \\
\hline
\end{tabular}

a)The values given are means of three consecutive experiments \pm standard deviations

Table 3 Physicochemical properties of soybean oil 
The purified MEL is shown in Fig. 10. The crude MEL obtained after fermentation was purified to determine as accurately its structure and mass using NMR and LC-MS respectively [49]. Solvent extraction and column chromatography has been the most widely used downstream processing method for MEL at laboratory scale. However, no advancement in downstream processing of MEL appropriate for pilot and industrial-scale production has been reported [59]. Ultrafiltration (UF), a membrane filtration method used to concentrate, recover and purify various biomolecules based on their size and molecular mass, is an alternative method that can process large volumes of culture supernatants quickly, continuously and cost-effectively $[21,60]$. In the case of biosurfactants, selective separation by UF can be achieved due to its unique ability to form micelles at and above their CMC. These supramolecular micellar aggregates are retained by the relatively high molecular weight cut-off (MWCO) membranes, while lower molecular weight contaminants such as peptides, small proteins, salts and free amino acids are washed out [21, 61]. Mulligan and Gibbs [61] reported the recovery and purification of surfactin and rhamnolipids from complex fermentation broths in one UF step, while Lin and Jiang [62] used two-stage UF to recover 95\% surfactin from fermentation broths. In addition, Andrade et al. [40] successfully used UF to recover $80 \%$ MEL with $86 \%$ purity in one UF step in the laboratory and $500 \mathrm{ml}$ scale-up batch (using cross-flow filtration) [40]. Thus, membrane filtration can be used like ultrafiltration as an efficient and scalable process for the recovery and purification of biosurfactants including MEL [21].

\subsection{Biomass, residual glycerol and oil, and MEL content analysis}

The initial low MEL concentration indicated that the MEL was synthesized and stored intracellularly initially in the log phase and was then secreted out of the cells as it entered the stationary phase. The rapid use of oil showed that fatty acids not only provided the carbon source to the cells but also induced the extracellular production of MEL along with being a precursor of the hydrophobic moiety in the glycolipid biosurfactant. MEL is a secondary metabolite and hence its production and secretion is higher in the stationary phase than the log phase.

During fermentation, the rate of hydrophobic substrate utilization by $P$. antarctica cells depends on the forces interfering with direct cell-substrate contact. The cell-substrate contact is in turn dependent on the outer membrane of the cell that forms the initial cell component to contact with the substrates. Various cultivation conditions such as temperature, $\mathrm{pH}$, nutrient availability, medium composition and aeration influence the outer membrane of the cell $[23,63$, 64], thus, the adaptation of the outer membrane is vital in the attachment and the utilization of hydrophobic substrates $[23,63]$. The addition of hydrophobic substrate in excess leads to an accumulation of oil in the culture medium which increases the broth viscosity, decreases the dissolved oxygen and causes the product inhibition by obstructing access of nutrients to the microbes in the fermentation medium, thereby impacting the microbial growth and productivity [23]. Dolman et al. [65] reported that the existence of two separate phases remarkably reduces the oxygen mass transfer coefficient due to the resistance of the mass transfer at the air/liquid interface which increases the viscosity of the

\begin{tabular}{|c|c|c|}
\hline Test & Method & Value \\
\hline Water content $(\% \mathrm{w} / \mathrm{w})$ & Oven drying method $\left(\right.$ at $\left.105^{\circ} \mathrm{C}\right)$ & 86.4 \\
\hline Glycerol content $(\% \mathrm{w} / \mathrm{w})$ & AOCS method Ea $6-51[31]$ & 10.6 \\
\hline Alkalinity $\left(\mathrm{OH}^{-}\right)($normality) & Back titrations with $0.1 \mathrm{~N} \mathrm{HCl}$ and $0.1 \mathrm{~N} \mathrm{NaOH}$ & 0.051 \\
\hline Specific gravity $\left(25^{\circ} \mathrm{C} / 25^{\circ} \mathrm{C}\right)$ & Specific gravity bottle & 1.018 \\
\hline Viscosity $(\mathrm{cP})$ & Brookfield viscometer & 1.15 \\
\hline Total residue $\left(\right.$ at $\left.160^{\circ} \mathrm{C}\right)(\% \mathrm{w} / \mathrm{w})$ & Oven drying at $160^{\circ} \mathrm{C}$ till constant weight $[58]$ & 1.52 \\
\hline
\end{tabular}

Table 4 Analysis of sweetwater

\begin{tabular}{|c|c|c|c|}
\hline Hydrophobic substrate & Hydrophilic substrate & MEL yield/g L-1 & Reference \\
\hline- & Glucose & 5.6 & {$[49]$} \\
\hline- & Glucose & 29 & {$[45]$} \\
\hline Soybean oil & Glucose & 4.8 & 13.5 \\
\hline- & Xylose & 5.61 & {$[13]$} \\
\hline Soybean oil & Sucrose & 3.62 & {$[17]$} \\
\hline- & Honey & 3.62] & {$[22]$} \\
\hline
\end{tabular}

Table 5 Effect of various hydrophilic carbon sources on MEL yield 
medium leading to an oxygen limitation and non-homogeneity of the broth $[23,65]$. In case of soybean oil, increasing the concentration from $7 \%(\mathrm{w} / \mathrm{v})$ to $8 \%(\mathrm{w} / \mathrm{v})$ may lead to a reduction in the biomass concentration due to the oxygen limitation, thereby decreasing the MEL yield [23].

\subsection{TLC and FTIR}

The TLC results shown in Fig. 5 were similar to the values previously reported by Patil et al., Fukuoka et al., and Kitamoto et al. [22, 35, 47], thus confirming the presence of MEL.

The FTIR spectrum displayed in Fig. 6 shows a peak at $3007 \mathrm{~cm}^{-1}$ indicating the presence of a hydroxyl $(-\mathrm{OH})$ group. The peaks in the range of $3000 \mathrm{~cm}^{-1}-2800 \mathrm{~cm}^{-1}$ at $2926 \mathrm{~cm}^{-1}$ and $2854 \mathrm{~cm}^{-1}$ represented an alkyl $(-\mathrm{C}-\mathrm{H})$ chain. The sharp peak at $1741 \mathrm{~cm}^{-1}$ indicates the presence of carbonyl $(\mathrm{C}=\mathrm{O})$ group. The peak at $1456 \mathrm{~cm}^{-1}$ signified a $(-\mathrm{C}-\mathrm{H})$ bond. The peaks at $1240 \mathrm{~cm}^{-1}$ and $1174 \mathrm{~cm}^{-1}$ confirmed the presence of (-C-O) linkage and the peak at $1093 \mathrm{~cm}^{-1}$ showed the presence of a dialkyl ether (-C-O-C) linkage [22].

\subsection{LC-MS}

As described by Onghena et al. [50], the varied peak pattern observed in the LC-MS separation with the C18 column is based on the hydrophobicity; i.e. the fatty acid chains that are incorporated in the MEL. MEL was eluted due to their polarity with respect to the polarity of the mobile phase. The slight differences in the mass-to-charge ratio are due to the use of Pseudozyma antarctica cells in the work. As shown in Fig. 11 adducts of sodium $[\mathrm{M}+\mathrm{Na}]^{+}$was detected as the most abundant ion for MEL $[50,51]$.

\subsection{Surfactant properties of MEL}

\subsubsection{Surface tension measurement}

Surfactants are amphiphilic compounds consisting of a hydrophobic moiety and a hydrophilic group. Thus, the addition of surfactants to liquids reduces the surface tension in an aqueous medium. The synthesized MEL are non-ionic glycolipid biosurfactants and thus their surface tension was

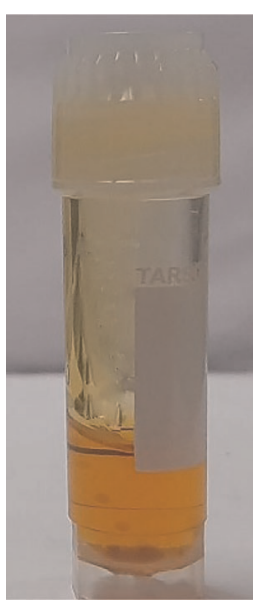

Figure 10 Purified mannosylerythritol lipids produced by Pseudozyma antarctica (MTCC 2706) at shake flask level, $30^{\circ} \mathrm{C}, 200 \mathrm{rpm}, 7$ days analyzed and compared to that of the non-ionic chemical surfactant polysorbate 80 (Tween 80 ). Depending on the hydrophilic and the lipophilic part of molecules, MEL shows variations in their surfactant properties like surface tension, interfacial tension, CMC, etc. [25]. The ability of MEL to reduce the surface tension of water better than polysorbate 80 indicates that MEL can replace chemical surfactants such as Polysorbate 80 when reducing the surface tension of liquids.

\subsubsection{Critical Micelle Concentration (CMC)}

The CMC of a surfactant is defined as the minimum concentration at which the surfactant solution provides maximum reduction in surface tension. Thus, low CMC values indicate that the surfactant can effectively reduce the surface tension at minimum concentration. The CMC of a surfactant depends on the surfactant molecule structure, so structural variations can influence the ability of a surfactant to reduce surface tension [25]. The low CMC value shown in Fig. 7 reveals that MEL reduces surface tension well even at lower concentrations, making MEL a potential alternative to a chemical non-ionic surfactant [17].

\subsubsection{Foaming studies and emulsion stability}

One of the crucial parameters in selecting a biosurfactant is its foamability. Thus, foaming characteristics of MEL were evaluated and compared to polysorbate 80 which is a nonionic chemical surfactant. The low foaming obtained for MEL could be due to the presence of more fatty acids in the crude MEL structure since the presence of fatty acid affects the foaming ability of surfactants. The foaming stability studies shown in Fig. 12 evaluated that the foam produced by MEL was stable for 30 min thus indicating the good stability of foam produced by the biosurfactant.

An important criterion for selecting a surfactant in food and cosmetic application is the emulsifying power. The emulsion formed by MEL was more stable than that formed by polysorbate 80 . Hence, chemical surfactants like polysorbate 80 can be efficiently replaced by the biosurfactant MEL for use in food and/or cosmetic industries [25].

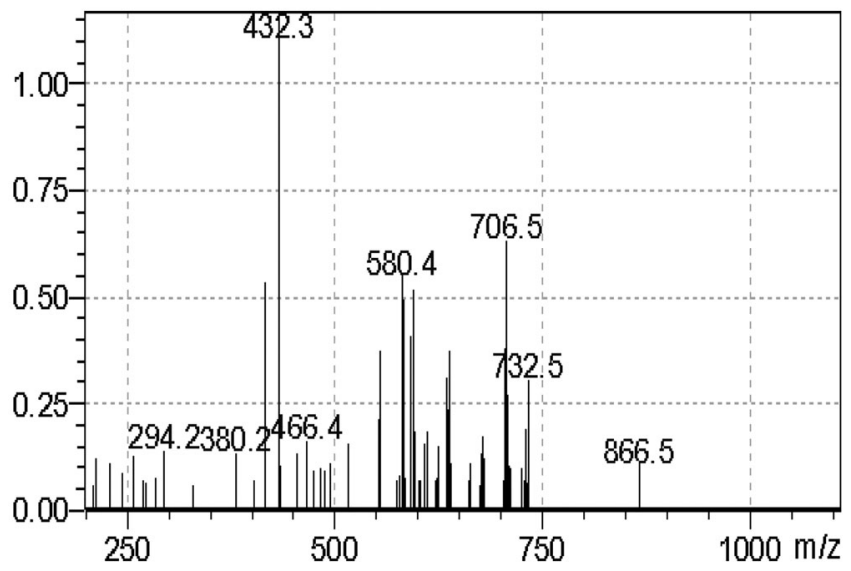

Figure 11 LC-MS spectrum of purified mannosylerythritol lipid to study the structure of MEL with Shimadzu 8040 equipped with ESI and Triple Quadrupole MS spectrometer 


\subsubsection{Antimicrobial activity of MEL}

MEL are strongly active against gram-positive bacteria and weakly active against gram-negative bacteria, but inactive against fungi $[13,66]$. The synthesized MEL showed growth inhibition against gram-positive $S$. aureus due to its high surface activity, which damaged the bilayer cell membranes of the microbe [49]. Previous studies showed that S. aureus cells treated with MEL became irregular, holey and shrunk. In addition, they exhibited anomalies with voids from the edge to the cell wall, affecting cell membrane permeability and integrity, leading to electrolyte leakage and metabolic pathway damage [67]. Kitamoto et al. [66] reported that MEL showed relatively good antimicrobial activities among the biosurfactants studied so far. It has also been reported that the number and/or position of the ester fatty acid influences the antimicrobial activity of MEL. Therefore, biosurfactants with higher hydrophobicity among homologues were more effective against the gram-positive bacteria. The antimicrobial activity of MEL in the present study was similar to that of the synthetic surfactants of the glycolipid type as well as that of the other biosurfactants [66]. This shows that MEL has good antimicrobial activity and can be used in the pharmaceutical, food and biomedical industries [49].

\section{Conclusion}

Fermentative production of mannosylerythritol lipids using sweetwater as the hydrophilic substrate by Pseudozyma antarctica yielded $7.52 \mathrm{~g} \mathrm{~L}^{-1}$ MEL after 7 days. The production of MEL was also studied in $5 \mathrm{~L}$ bioreactor and the obtained yield of the product was $21.5 \mathrm{~g} \mathrm{~L}^{-1}$. The combination of sweetwater with soybean oil gave a better MEL yield because both the hydrophilic as well as the hydrophobic part were readily available for MEL production and did not require any de-novo synthesis. The production using sweetwater delivered a yield of MEL comparable to that of conventional substrates. This confirmed the use of sweetwater as the hydrophilic carbon source. Hence, by-product like sweetwater can be efficiently used for MEL to reduce the raw material cost and convert a by-product into a value-added product. The one-solvent heating method can efficiently be used for the extraction of MEL. It showed an advantage over the solvent extraction method in

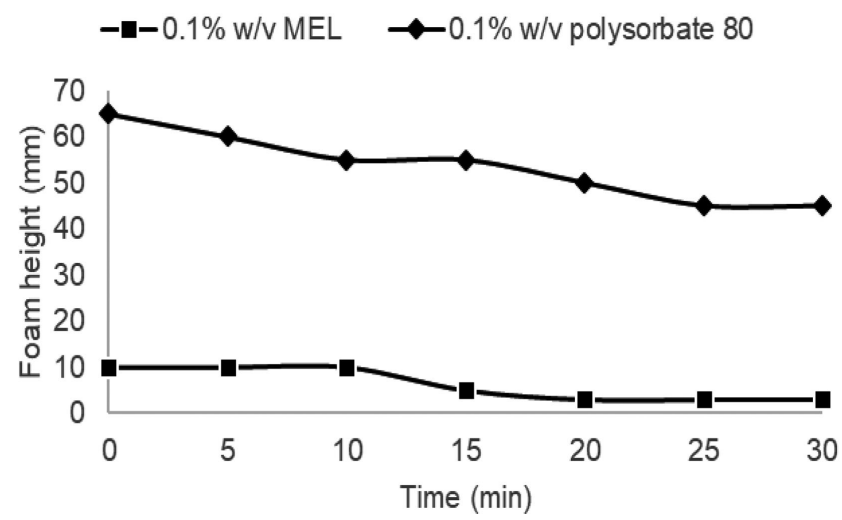

Figure 12 Foaming studies of mannosylerythritol lipids produced by $\mathrm{Pseu}$ dozyma antarctica (MTCC 2706) compared to polysorbate 80 of $0.1 \%$ (w/v) surfactant concentration terms of better extraction and higher recovery. Additionally, the solvent used was recovered to extract the product. Thus, the one-solvent heating method can be used in order to extract MEL with lesser solvent use thereby further trying to reduce the downstream processing cost. The antimicrobial and surfactant properties of MEL open up possibilities for its application as an active ingredient in cosmetics and skincare formulations.

\section{Conflict of interest}

The authors declare that they have no conflict of interest.

\section{Acknowledgements}

The authors are thankful to Department of Biotechnology (Govt. of India), New Delhi for student fellowship. Authors are also thankful to Shobhaben Pratapbhai Patel School of Pharmacy Q Technology Management (SPPSPTM), SVKM, NMIMS, Mumbai, Maharashtra, India for allowing to perform the LC-MS analysis at their facility.

\section{References}

1. Saharan, B. S., Sahu, R. K. and Sharma, D.: A review on biosurfactants: fermentation, current developments and perspectives, Genetic Engineering and Biotechnology Journal, 2011 (2011) $1-14$.

2. Arutchelvi, J. and Doble, M.: Mannosylerythritol lipids: microbial production and their applications, in: Gloria, S. C. (Ed.), Biosurfactants. Microbiology Monographs, Springer, Berlin (2010) 20, 145- 177. DOI:10.1007/978-3-642-14490-5 6

3. Claus, S. and Van Bogaert, I. N. A.: Sophorolipid production by yeasts: a critical review of the literature and suggestions for future research,Applied Microbiology and Biotechnology, 101 (2017) 7811 - 7821. PMid:28929199; DOI: 10.1007/s00253-017-8519-7

4. Van Bogaert, I. N. A., Zhang, J. and Soetaert, W.: Microbial synthesis of sophorolipids, Process Biochemistry, 46 (2011) $821-833$. DOl:10.1016/j.procbio.2011.01.010

5. Van Bogaert, I. N. A., Saerens, K., Muynck, C., Develter, D., Soetaert, W. and Vandamme, E. J.: Microbial production and application of sophorolipids,Applied Microbiology and Biotechnology, 76 (2007) 23-34. PMid:17476500; DOI:10.1007/s00253-007-0988-7

6. Makkar, R. S. and Cameotra, S. S.: An update on the use of unconventional substrates for biosurfactant production and their new applications,Applied Microbiology and Biotechnology, 58 (2002) 428-434. PMid:11954787; DOI: 10.1007/s00253-001-0924-1

7. Imura, T., Ohta, N., Yagi, N., Negishi, H., Yanagishita H. and Kitamoto, D.: Naturally engineered glycolipid biosurfactants leading to distinctive self-assembled structures, Chemistry, 12 (2006) 2434-40. PMid:16374891; DOI:10.1002/chem.200501199

8. Akbari, S., Abdurahman, N. H., Yunus, R. M., Fayaz, F. and Alara, O. R.: Biosurfactants-a new frontier for social and environmental safety: a mini review,Biotechnology Research and Innovation, 2 (2018) $81-90$. DOI:10.1016/j.biori.2018.09.001

9. Banat, I. M., Franzetti, A., Gandolfi, I., Bestetti, G., Martinotti, M. G., Fracchia, L. Smyth, T. J. and Marchant, R.: Microbial biosurfactants production, applications and future potential,Applied Microbiology and Biotechnology, 87 (2010) 427 444. PMid:20424836; DOI:10.1007/s00253-010-2589-0

10. Lourith, N. and Kanlayavattanakul, M.: Natural surfactants used in cosmetics: glycolipids, International Journal of Cosmetic Science, 31 (2009) 255-261. PMid:19496839; DOI:10.1111/j.1468-2494.2009.00493.x

11. Spoeckner, S., Wray, V., Nimtz, M. and Lang, S.: Glycolipids of the smut fungus Ustilago maydis from cultivation on renewable resources, Applied Microbiology and Biotechnology, 51 (1999) 33-39. DOI:10.1007/s002530051359

12. Santos, D. K. F. Rufino, R. D. Luna, J. M. Santos, V. A. and Sarubbo, L. A. Biosurfactants: multifunctional biomolecules of the 21 st century, International Journal of Molecular Sciences, 17 (2016) 401. PMid:26999123; DOI: 10.3390/ijms 17030401

13. Arutchelvi, J. I., Bhaduri, S., Uppara, P. V. and Doble, M.: Mannosylerythritol lipids: a review, Journal of Industrial Microbiology \& Biotechnology, 35 (2008) 1559 - 1570. PMid: 18716809; DOI:10.1007/s 10295-008-0460-4

14. Yu, M., Kiu, Z., Zeng, G. and Zhong, H.: Characteristics of mannosylerythritol lipids and their enviornmental potential,Carbohydrate Research, 407 (2015) 63-72. PMid:25723622; DOI:10.1016/j.carres.2014.12.012

15. Morita, T., Fukuoka, T., Imura, T. and Kitamoto, D.: Mannosylerythritol lipids: production and applications,Journal of Oleo Science, 64 (2015) $133-141$. PMid:25748373; DOI:10.5650/jos.ess 14185 
16. Konishi, M., Morita, T., Fukuoka, T., Imura, T., Kakugawa, K. and Kitamoto, D.: Production of different types of mannosylerythritol lipids as biosurfactants by the newly isolated yeast strains belonging to the genus Pseudozyma Applied Microbiology and Biotechnology, 75 (2007) 521 -531. PMid:17505770; DOI: 10.1007/s00253-007-0853-8

17. Bhangale, A., Wadekar, S., Kale, S. and Pratap, A. P.: Optimization and monitoring of water soluble substrate for synthesis of mannosylerythritol lipids by Pseudozyma antarctica (ATCC 32657), Biotechnology and Bioprocess Engineering, 18 (2013) 679-685. DOI:10.1007/s 12257-012-0647-4

18. Morita, T., Takashima, M., Fukuoka, T., Konishi, M., Imura, T. and Kitamoto, D.: Isolation of basidiomycetous yeast Pseudozyma tsukubaensis and production of glycolipid biosurfactant, a diastereomer type of mannosylerythritol lipidB,Applied Microbiology and Biotechnology, 88 (2010) 679-688. PMid:20652239; DOI:10.1007/s00253-010-2762-5

19. Banat, I. M., Makkar, R. S. and Cameotra, S. S.: Potential commercial applications of microbial surfactants, Applied Microbiology and Biotechnology, 53 (2000) 495 - 508. PMid: 10855707· DOl:10.1007/s002530051648

20. Vecino, X., Cruz, J. M., Moldes, A. B. and Rodrigues, L. R.: Biosurfactants in cosmetic formulations: trends and challenges, Critical Reviews in Biotechnology, 37 (2017) 911 - 923. PMid:28076995; DOl:10.1080/07388551.2016.1269053

21. Jauregi, P. and Kourmentza, K.: Membrane filtration of biosurfactants, in: Galanakis, C. M. (Ed.), Separation of Functional Molecules in Food by Membrane Technology, ElsevierAcademic Press, (2019) 79-112. DOI:10.1016/B978-0-12-815056-6.00003-6

22. Patil, S. V., Wadekar, S. D., Lali, A. M., Bhowmick, D. N. and Pratap, A. P.: Effect of glycerol and soybean oil as a carbon source on the production of mannosylerythritol lipids by Pseudozyma antarctica (ATCC 32657), Journal of Lipid Science and Technology, 43 (2011) 16-20.

23. Jadhav, J. V., Anbu, P., Yadav, S., Pratap, A. P. and Kale, S. B.: Sunflower acid oilbased production of rhamnolipid using Pseudomonas aeruginosa and its application in liquid detergents, Journal of Surfactants and Detergents, 22 (2019) 463-476. DOI: 10.1002/jsde.12255

24. Niu, Y., Wu, J., Wang, W. and Chen, Q.: Production and characterization of a new glycolipid, mannosylerythritol lipid, from waste cooking oil biotransformation by Pseudozyma aphidis ZJUDM34, Food Science \& Nutrition, 7 (2019) 937-948. PMid:30918636; DOI: 10.1002/fsn3.880

25. Jadhav, J. V., Pratap, A. P. and Kale, S. B.: Evaluation of sunflower oil refinery waste as feedstock for production of sophorolipid, Process Biochemistry, 78 (2019) 15-24. DOI:10.1016/j.procbio.2019.01.015

26. Wadekar, S. D., Patil, S., Kale, S. B., Lali, A. M. and Pratap, A. P.: Study of glycerol and sweet water as a carbon source for production of rhamnolipids by naturally occurring strains of Pseudomonas aeruginosa (ATCC 10145 and ATCC 9027), Tenside Surfactants Detergents, 47 (2010) 238-242. DOI: $10.3139 / 113.110073$

27. Wadekar, S. D., Kale, S. B., Lali, A., Bhowmick, D. N. and Pratap, A. P.: Utilization of sweetwater as a cost-effective carbon source for sophorolipids production by Starmerella bombicola (ATCC 22214),Preparative Biochemistry \& Biotechnology, 42 (2012) 125 - 142. PMid:22394062 DOI: $10.1080 / 10826068.2011 .577883$

28. Burke, M. R.: Industrial and nonedible products from oils and fats, in: Shahidi, F.(Ed.), Bailey's Industrial Oil and Fat Products, A John Wiley \& Sons Inc., New Jersey (2005) $6191-221$.

29. Wadekar, S. D., Patil, S. V., Kale, S. B., Lali, A. M. and Pratap, A. P.: Structural elucidation and surfactant properties of rhamnolipids synthesized by Pseudomonas aeruginosa (ATCC 10145) on sweet water as carbon source and stabilization effect on foam produced by sodium lauryl sulfate,Tenside Surfactants Detergents, 48 (2011) 286-292. DOI:10.3139/113.110132

30. Jadhav, J., Dutta, S., Kale, S. and Pratap, A. P.: Fermentative production of rhamnolipid and purification by adsorption chromatography, Preparative Biochemistry and Biotechnology, 48 (2018) 234-241. PMid:29313452; DOI: $10.1080 / 10826068.2017 .1421967$

31. A.O.C.S. Method Ea 6-51, in: Firestone, D. (Ed.), Official Methods and Recommended Practices of the American Methods and Recommended Practices of the American Oil Chemists' Society, AOCS Press, Illinois (1994).

32. Morita, T., Konishi, M., Fukuoka, T., Imura, T., Kitamoto, H. K. and Kitamoto, D. Characterization of the genus Pseudozyma by the formation of glycolipid biosurfactants, mannosylerythritol lipids, FEMS Yeast Res., 7 (2007) 286-292. PMid:17328742; DOI:10.1111/j.1567-1364.2006.00154.x

33. Morita, T., Konishi, M., Fukuoka, T., Imura, T., Yamamoto, S., Kitagawa, M., Sogabe, A. and Kitamoto, D.: Identification of Pseudozyma graminicola CBS 10092 as a producer of glycolipid biosurfactants, mannosylerythritol lipids, Journal of Oleo Science, 57 (2008) 123-131. PMid:18198469; DOI: 10.5650/jos.57.123

34. Bajaj, V., Tilay, A. and Annapure, U.: Enhanced production of bioactive sophorolipids by Starmerella bombicola NRRL Y-17069 by design of experiment approach with successive purification and characterization, Journal of Oleo Science, 61 (2012) 377-386. PMid:22790168; DOI: 10.5650/jos.61.377

35. Fukuoka, T., Kawamura, M., Morita, T., Imura, T., Sakai, H., Abe, M. and Kitamoto, D.: A basidiomycetous yeast, Pseudozyma crassa produces novel diastereomers of conventional mannosylerythritol lipids as glycolipid biosurfactants, Carbohydrate Research, 343 (2008)2947-2955. PMid: 18805521; DOI:10.1016/j.carres.2008.08.034

36. Rau, U., Nguyen, L. A., Roeper, H., Koch, H. and Lang, S.: Downstream processing of mannosylerythritol lipids produced by Pseudozyma aphidis, European Journal of Lipid Science and Technology, 107 (2005) 373-380. DOI:10.1002/ejlt.200401122
37. Fukuoka, T., Morita, T., Konishi, M., Imura, T. and Kitamoto, D.: Characterization of new types of mannosylerythritol lipids as biosurfactants produced from soybean oil by a basidiomycetous yeast, Pseudozyma shanxiensis, Journal of Oleo Science, 56 (2007) 435-442. PMid:17898510; DOI: $10.5650 /$ jos.56.435

38. Katsuki, T. and Sharpless, K. B.: The first practical method for asymmetric epoxidation, Journal of the American Chemical Society, 102 (1980) 5974 5976. DOI: $10.1021 / \mathrm{ja00538a077}$

39. Fan, L. L., Dong, Y. C., Fan, Y. F., Zhang, J. and Chen, Q. H.: Production and identification of mannosylerythritol lipid-A homologs from the Ustilaginomycetous yeast Pseudozyma aphidis ZJUDM34, Carbohydrate Research, 392 (2014) 1-6. PMid:24814655; DOl:10.1016/j.carres.2014.04.013

40. d. Andrade, C. J., d. Andrade, L. M., Rocco, S. A., Sforça, M. L., Pastore, G. M. and Jauregi, P.: A novel approach for the production and purification of mannosylerythritol lipids (MEL) by Pseudozyma tsukubaensis using cassava wastewater as substrate, Separation and Purification Technology, 180 (2017) 157- 167. DOI:10.1016/j.seppur.2017.02.045

41. Bhangale, A., Patil, S., Wadekar, S., Kale, S., Lali, A., Bhowmick, D. and Pratap, A. P.: Stabilization of foam produced by sodium lauryl sulphate with mannosylerythritol lipids synthesized on soybean oil and sucrose by Pseudozyma antarctica (ATCC 32657), Tenside Surfactants Detergents, 50 (2013) 131 - 136. DOI: $10.3139 / 113.110240$

42. Ross, J. and Miles, G. D.: An apparatus for comparison of foaming properties of soaps and detergents, Oil and Soap, 18(1941) 99-102. DOI: 10.1007/BF02545418

43. Subrahmanyam, V.R. and Achaya, K. T.: Structure and surfactance- evaluation of ricinoleyl alcohol, Journal of Chemical \& Engineering Data, 6 (1961) 38-42. DOI: 10.1021/je60009a012

44. Sudha, S., Raghunathan, K., Vijayashree, P. and Muthusamy, K.: Comparative study for the production, characterisation and antimicrobial studies of sophorolipids using Candida tropicalis, Asian Journal of Pharmaceutical and Clinical Research, 3 (2010) 69-72.

45. Faria, N. T., Santos, M. V., Fernandes, P., Fonseca, L. L., Fonseca, C. and Ferreira, F. C.: Production of glycolipid biosurfactants, mannosylerythritol lipids, from pentoses and d-glucose/d-xylose mixtures by Pseudozyma yeast strains,Process Biochemistry, 49 (2014) $1790-1799$. DOI: 10.1016/j.procbio.2014.08.004

46. Kim, H. S., Yoon, B. D., Choung, D. H., Oh, H. M., Katsuragi, T. and Tani, Y.: Characterization of a biosurfactant, mannosylerythritol lipid produced from Candida sp. SY16, Applied Microbiology and Biotechnology, 52 (1999) 713-721. PMid:10570818; DOl:10.1007/s002530051583

47. Kitamoto, K. H., Nakahara, T. and Tabuchi, T.: Production of mannosylerythrito lipids by Candida antarctica from vegetable oils, Agric. Biol. Chem, 54 (1990) 37-40. DOI:10.1271/bbb 1961.54.37

48. Faria, N. T., Santos, M., Ferreira, C., Marques, S., Ferreira, F. C. and Fonseca, C.: Conversion of cellulosic materials into glycolipid biosurfactants, mannosylerythritol lipids, by Pseudozyma spp. under SHF and SSF processes,Microbial Cell Factories, 13 (2014) 155 - 168. PMid:25366184; DOI:10.1186/s 12934-014-0155-7

49. Fukuoka, T., Morita, T., Konishi, M., Imura, T., Sakai, H. and Kitamoto, D.: Structural characterization and surface-active properties of a new glycolipid biosurfactant, mono-acylated mannosylerythritol lipid, produced from glucose by Pseudozyma antarctica, Applied Microbiology and Biotechnology, 76 (2007) 801 -810. PMid: 17607573; DOl:10.1007/s00253-007-1051-4

50. Onghena, M., Geens, T., Goossens, E., Wijnants, M., Pico, Y., Neels, H., Covaci, $A$. and Lemiere, F.: Analytical characterization of mannosylerythritol lipid biosurfactants produced by biosynthesis based on feedstock sources from the agrofood industry, Analytical and Bioanalytical Chemistry, 400 (2011) 1263 1275. PMid:21318245; DOI: 10.1007/s00216-011-4741-9

51. Goossens, E., Wijnants, M., Packet, D. and Limiere, F.: Enhanced separation and analysis procedure reveals production of triacylated mannosylerythritol lipids by Pseudozyma aphidis,Journal of Industrial Microbiology and Biotechnology, 43 (2016) 1 - 14. PMid:27659961; DOI:10.1007/s 10295-016-1838-3

52. Fan, L., Li, H., Niu, Y. and Chen, Q.: Characterization and inducing melanoma cell apoptosis activity of mannosylerythritol lipids-A produced from Pseudozyma aphidis, PLoS ONE, 11 (2016) 1 - 17. PMid:26828792; DOI: $10.1371 /$ journal.pone.0148198

53. Morita, T., Konishi, M., Fukuoka, T., Imura, T., Sakai, H. and Kitamoto, D.: Efficient production of di- and tri-acylated mannosylerythritol lipids as glycolipid biosurfactants by Pseudozyma parantarctica JCM 11752, Journal of Oleo Science, 57 (2008) 557-565. PMid:18781056; DOI:10.5650/jos.57.557

54. American Oil Chemists' Society, in: Firestone, D. (Ed.), Official Methods and Recommended Practices of the American Oil Chemists' Society, AOCS Press, (1994).

55. Beck, A., Haitz, F., Grunwald, S., Preuss, L., Rupp, S. and Zibek, S.: Influence of microorganism and plant oils on the structure of mannosylerythritol lipid (MEL) biosurfactants revealed by a novel thin layer chromatography mass spectrometry method, Journal of Industrial Microbiology \& Biotechnology, 46(2019) 1191 - 1204. PMid:31175524; DOI:10.1007/s10295-019-02194-2

56. Bailey, A. E.: Industrial Oil and Fat Products, Interscience Publishers Inc., New York (1945) 9- 11.

57. Burke, M. R.: Industrial and nonedible products from oils and fats, in: Shahidi, F.(Ed.), Bailey's Industrial Oil and Fat Products, A John Wiley \& Sons Inc., New Jersey(2005) 6103-136

58. Shahidi, F.: Edible Oil and Fat Products: Edible Oils, in: Shahidi, F. (Ed.), Bailey's Industrial Oil and Fat Products, A John Wiley \& Sons Inc., New York (2005) 2. DOI: 10.1002/047167849X 
59. Beck, A., Werner, N. and Zibek, S.: Mannosylerythritol lipids: biosynthesis, genetics, and production strategies, in: Hayes, D. G., Solaiman, D. K. Y. and Ashby, R. D. (Ed.),Biobased Surfactants, AOCS Press Elsevier Inc., (2019) 121 - 167. DOI: 10.1016/C2016-0-03179-0

60. Najmi, Z., Ebrahimipour, G., Franzetti, A. and Banat, I. M.: In situ downstream strategies for cost-effective bio/surfactant recovery,Biotechnology and Applied Biochemistry, 65 (2018) 523-532: PMid:29297935: DOl:10.1002/bab.1641

61. Mulligan, C. N. and Gibbs, B. F.: Recovery of biosurfactants by ultrafiltration,Journal of Chemical Technology \& Biotechnology, 47 (1990) 23-29. PMid:1367444; DOI:10.1002/jctb.280470104

62. Lin, S. C. and Jiang, H. J.: Recovery and purification of the lipopeptide biosurfactant of Bacillus subtilis by ultrafiltration,Biotechnology Techniques, 11 (1997) 413-416. DOI:10.1023/A: 1018468723132

63. Norman, R. S., Frontera-Suau, R. and Morris, P. J.: Variability in Pseudomonas aeruginosa lipopolysaccharide expression during crude oil degradation, Applied and Environmental Microbiology, 68 (2002) 5096-5103. PMid:12324360: DOI:10.1128/AEM.68.10.5096-5103.2002

64. Dziegielewska, E. and Adamczak, M.: Evaluation of waste products in the synthesis of surfactants by yeasts, Chemical Papers, 67 (2013) 1113-1122. DOI:10.2478/s11696-013-0349-1

65. Dolman, B., Kaisermann, C., Martin, P. and Winterburn, J.: Integrated sophorolipid production and gravity separation, Process Biochemistry, 54 (2017) 162 - 171. DOI:10.1016/j.procbio.2016.12.021

66. Kitamoto, D., Yanagishita, H., Shinbo, T., Nakane, T., Kamisawa, C. and Nakahara, T: Surface active properties and antimicrobial activities of mannosylerythritol lipids as biosurfactants produced by Candida antarctica, Journal of Biotechnology, 29 (1993) 91 -96. DOI:10.1016/0168-1656(93)90042-L

67. Shu, Q., Wei, T., Lu, H., Niu, Y. and Chen, Q.: Mannosylerythritol lipid: dual inhibitory modes against Staphylococcus aureus through membrane-mediated apoptosis and biofilm disruption,Applied Microbiology and Biotechnology, 104 (2020) 5053 - 5064. PMid:32248439; DOI:10.1007/s00253-020-10561-8

68. Chen, S. Y., Lu, W. B., Wei, Y. H., Chen, W. M. and Chang, J. S.: Improved production of biosurfactant with newly isolated Pseudomonas aeruginosa S2, Biotechnology Progress, 23 (2007) 661 -666. PMid:17461551; DOI: 10.1021/bp0700152

Received: 19.04 .2020

Accepted: 13.07.2020

Bibliography

DOI 10.1515/tsd-2020-2272

Tenside Surf. Det. 58 (2021) 4, page 246-258

(c) 2021 Walter de Gruyter GmbH, Berlin/Boston, Germany

ISSN 0932-3414 · e-ISSN 2195-8564

\section{Correspondence address}

\section{Professor (Dr.) Amit P. Pratap}

Department of Oils, Oleochemicals and Surfactants Technology

Institute of Chemical Technology

(University under Section 3 of UGC Act 1956

Maharashtra Government's "Elite Status and Center of Excellence"

formerly UDCT/UICT, University of Mumbai)

Nathalal Parekh Road

Matunga (East), Mumbai-400 019

INDIA

Tel.: 91- 22- 33612556

Fax: 91- 22- 33611020

Cell: 91-92210 48682, 9930040853

E-mail: amitpratap0101@rediffmail.com amitpratap2001@gmail.com

\section{The authors of this paper}

Ms. Jayata Mawani - Co-author, completed her M. Tech. (Bioprocess Technology) from Institute of Chemical Technology, Matunga (East), Mumbai - 400 019, Maharashtra, India. Her research interests are microbial biosurfactants and their applications in pharma and biomedicine.

Dr. Jagruti Jadhav - Co-author, completed M. Tech. (Green Technology) and Ph.D. (Tech.) from Institute of Chemical Technology, Matunga (East), Mumbai - 400019 , Maharashtra, India. The research interests are organic/enzymatic synthesis of surfactants, microbial biosurfactants, specialty products and applications.

Professor (Dr.) Amit P. Pratap - Corresponding Author, completed his graduation and post graduation in Technology of Oils, Oleochemicals and Surfactants Technology and obtained Ph.D. (Tech.) from ICT. At present he is working as Professor and Head of the Department of Oils, Oleochemicals and Surfactants Technology at Institute of Chemical Technology, Matunga (East), Mumbai - 400 019, Maharashtra, India. His research interests are biolubricants, microbial biosurfactants, specialty products and applications 